\section{Field Checking List Of Saskatchewan Birds}

A new Saskatchewan field checking card has been prepared by Fred G. Bard and Dr. Stuart Houston, to replace those that have been distributed by the Yorkton Natural History Society, but are now out of print.

This list is useful as a ready reference, listing the 298 species that have been definitely identified in Saskatchewan to the present time, plus ten hypothetical species whose status is still doubtful. It is also of value as a handy means of recording the species seen on a nature outing, and some of our ornithologists keep their records in this manner. It has been useful at summer camps and bird hikes to help the boys to record and remember the species they have seen.

The publishing of this list has been sponsored by the Yorkton, Regina and Prince Albert Natural History Societies and copies may be ordered from their respective secretaries ( $5 c$ per copy, or 30 cards for 50c):

Cliff Shaw, 155 Fifth Ave., Yorkton.

Mrs. G. F. Ledingham, 2335 Athol St., Regina.

Miss Grace Crooks, Regional Library, Prince Albert.

\section{Spring (?) 1954 \\ Mrs. John Hubbard Grenfell, Sask.}

April 24 and not a flower in sight. Hardly a blade of green grass, just a few pussy-willows. Has Spring forgotten us?

But what is that out in the garden among last year's tomato vines? Ripe tomatoes! Good gracious no, just a flock of bright-breasted Robins.

I guess we don't need to worry the birds haven't deserted us anyway and have been coming back at about average dates for their species. Six big white swans were seen on the flats near Grenfell Easter week and these are surely a wonderful thing to see.

\section{Comments on The Last Issue

\author{
Mrs. T. Harold Bray,
} McLean, Sask.}

May I say how pleased I am that the name of our wonderful magazine will remain unchanged - that is as it should be, as a tribute to the work of its worthy founder, Isabel Priestly. The last issue was, to my mind, outstanding. Especially worthy of mention was the sprightly discussion of the Meadowlarks' song, but then all articles were of equal value - so beautifully worded.

Of particular interest was Frank Baines' article concerning the Sharptailed Grouse. I, too, feel very strongly that a closed season should be declared indefinitely or until we are reasonably sure that they are passed the danger of extinction. Surely hunters would be willing to co-operate if they wish to be assured of future hunting - at least the true sportsman would be. What do other naturalists think?

\section{Spring Migration Notes}

\section{Arthur Ward, Swift Current,}

Cold snowy weather often causes a hangover for many species of birds during spring migration. Of the 42 birds 22 species banded in April, the most interesting was the Fox Sparrow. I have never before seen this large and handsome bird, and would suggest that it had been driven out of the usual line of migration. I was able to band five of them.

Two Sparrow Hawks lingered. One, taking a short flight, returned with a small bird clutched in its talons. A small bough in the poplar tree served as a table to hold the bird with both feet. I watched it through binoculars and noticed how easily it detached each mouthful, scarcely a feather falling to the ground. 